\title{
https://doi.org/10.46813/2021-134-204 \\ DETERMINATION OF THE OPTIMAL OZONATION MODE FOR WINTER GARLIC PLANTING MATERIAL
}

\author{
S.G. Pugach ${ }^{1}$, L.M. Zavada ${ }^{1}$, O.O. Zamuriev ${ }^{1}$, D.V. Kudin ${ }^{1}$, P.O. Opalev ${ }^{1}$, A.V. Melnyk', \\ S.A. Scherbina ${ }^{2}$, O.L. Semenchenko ${ }^{2}$ \\ ${ }^{1}$ National Science Center "Kharkov Institute of Physics and Technology”, Kharkiv, Ukraine; \\ ${ }^{2}$ Institute of Vegetable and Melon Farming of the NAAS of Ukraine, Kharkiv, Ukraine \\ E-mail: kudin@kipt.kharkov.ua
}

The study was carried out at the Institute of Vegetable and Melon Farming of the National Academy of Agrarian Sciences of Ukraine and the Department of Low-Temperature Non-equilibrium Plasma Chemistry of the NSC "Kharkov Institute of Physics and Technology" of the National Academy of Sciences of Ukraine using the varieties of winter garlic, such as Duchess and Merefyanskiy white. Pre-plant treatment with four-time repeatability was carried out 3-5 days before planting using an OzW Stream Ozone TM ozone generator. Laboratory studies of fungal diseases Fusarium and Penicillium progress on the treated material were carried out with four-time repeatability in wet chambers. The effect of ozone concentration of 10, 50, and 100 PPM and exposure time of 10, 60, and 180 min on infestation of garlic with black and green mold was studied.

PACS: 52.80. Hc, 52.90.+z,52.75.-d

\section{INTRODUCTION}

Garlic is one of the most important vegetables in terms of its health benefit and taste. Garlic post-harvest losses remain high, so there is a need to monitor the disease progress that can reduce its seed properties. Diseases caused by fungi Penicillium spp. and Fusarium spp., were identified during the post-harvest storage. Therefore, it is important to control these fungal pathogens using traditional or alternative measures.

Traditional methods, such as chemical treatments, are widely used to control these fungi. However, due to their environment and human health hazard, the environmentally friendly biological measures using antagonistic microbes are alternative methods. Biological treatment of fungal using antagonistic microbes is more efficient, but less reliable [1].

The disease incidence of garlic planting material largely depends on the growing conditions and varietal characteristics. Garlic chives are usually affected by saprophytic microflora found in soil and plant residues. The degree of disease manifestation, in most cases fungal, depends on the conditions of post-harvest storage [2] lasted 3-4 months for winter garlic. The existing methods of diseases inhibition are based on drying and heating the plant material, as well as using fungicidal disinfectants.

The use of gas-discharge technologies, in particular, ozonation, is a more effective method of decontamination. There are many recommendations on the modes of long-term storage of plant material in ozone-air environment [3 - 5]. However, the nuances of short-term storage with periodic ozonation by blowing ozone through the mass of products have not been sufficiently studied.

The use of ozone is based on its high oxidizing capacity. Destruction of harmful objects on the treated material surface does not cause negative changes in its quality $[3,4]$.

\section{MATERIALS AND METHODS}

Pre-plant treatment was carried with four-time repeatability out 3-5 days before planting using an OzW Stream Ozone TM ozone generator. Laboratory studies for fungal diseases Fusarium and Penicillium progress on the treated material were carried out with four-time repeatability in wet chambers. The ozone concentration of 10, 50, and 100 PPM and exposure time of 10, 60, and $180 \mathrm{~min}$ on were studied.

The garlic was treated on a laboratory stand "Ozoneagro-1L" (Figs. 1, 2). The stand is composed of the following functional units: Secoh sangyo (Japan) air compressor of capacity up to $50 \mathrm{1} / \mathrm{min}$ and of a maximum pressure of up to $12.7 \mathrm{kPa}$, a gas flow meter (type SM-4 GUZ), OzW Stream Ozone laboratory ozone generator, Teledyne instruments (USA) ozone concentration meters (model $454 \mathrm{H}$ ) of ozone concentration measurement range of $0.1 \ldots 100 \mathrm{~g} / \mathrm{m}^{3}$, Ozone Solutions (USA) (model ES-600) of ozone concentration measurement range of $0.01 \ldots 0.1 \mathrm{~g} / \mathrm{m}^{3}$ and StreamOzone1000 ozone concentration meters of ozone concentration measurement range up to 1000 PPM, a laboratory chamber for samples and an ozone destructor.

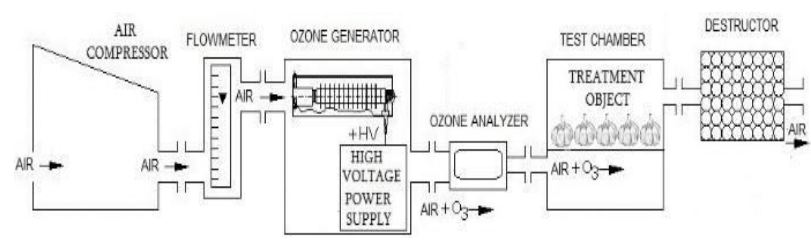

Fig. 1. Block diagram of the laboratory stand "Ozone-agro $1 L$ " functional units

We used barrierless ozone generators based on a streamer discharge of atmospheric pressure for ozone synthesis [6]. They have clear advantages over barrier ozone generators in agricultural industry. First of all, their low sensitivity to water vapor in the feeding gas, no need for precision assembly of the electrode system, no need for water cooling of electrodes, low resistance to pumping the gas mixture through the ozone generator module. They can steadily and durably produce ozone 
from ambient atmospheric air (without using a special air preparation system) of ozone-air mixture parameters required for garlic treatment.

The exterior view of the laboratory stand "Ozoneagro $1 \mathrm{~L} "$ is presented in Fig. 2.

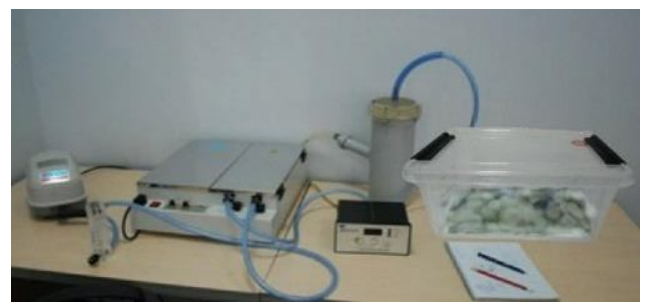

Fig. 2. Exterior view of the laboratory stand "Ozone-agro $1 L "$

To treat the plant material (chives) contaminated with a fungal infection in a latent form it was placed in a small-volume chamber on a mesh surface from under which an ozone-air mixture was fed into the chamber and evenly distributed throughout the volume through the entire mass of products. Table 1 shows treatment parameters.

Table 1

Parameters of garlic samples treatment with ozone

\begin{tabular}{|c|c|c|}
\hline № & Concentration, PPM & Time of exposure, min \\
\hline 1 & Reference sample (without treatment) \\
\hline 2 & \multirow{3}{*}{10} & 10 \\
\cline { 1 - 1 } 3 & & 60 \\
4 & \multirow{3}{*}{50} & 180 \\
\hline 5 & & 10 \\
\hline 6 & \multirow{3}{*}{100} & 60 \\
\hline 7 & & 180 \\
\hline 8 & & 10 \\
\hline 9 & & 60 \\
\hline 10 & & \\
& &
\end{tabular}

Samples of winter garlic varieties - Merefyanskiy white (medium ripening), Duchess (early ripening) were treated. Planting system $-70 \times 8 \mathrm{~cm}$. Multiplicity - four times. Fertilizers - N45P45K45 (basic) and N30 (additional nutrition). Drip irrigation. Planting - 10/25/2019. Harvesting -21.07 .2020 . Covering with a layer of straw of $10 \ldots 15 \mathrm{~cm}$ in autumn.

\section{RESULTS AND DISCUSSION}

Diseases level of the garlic planting material are given in Table 2.

Diseases level of garlic planting material, \%

\begin{tabular}{|c|c|c|c|c|}
\hline \multirow[b]{2}{*}{$\begin{array}{c}\text { Ser. } \\
\text { № }\end{array}$} & \multicolumn{2}{|c|}{ Merefyanskiy white } & \multicolumn{2}{|c|}{ Duchess } \\
\hline & $\begin{array}{l}\text { fusarium } \\
\text { (green } \\
\text { mold) }\end{array}$ & $\begin{array}{c}\text { penicillium } \\
\text { (white } \\
\text { mold) }\end{array}$ & $\begin{array}{l}\text { fusarium } \\
\text { (green } \\
\text { mold }\end{array}$ & $\begin{array}{l}\text { penicillium } \\
\text { (white } \\
\text { mold) }\end{array}$ \\
\hline 1 & 80 & 20 & 90 & 20 \\
\hline 2 & 60 & 20 & 80 & 20 \\
\hline 3 & 60 & 20 & 60 & 20 \\
\hline 4 & 40 & 10 & 60 & 20 \\
\hline 5 & 40 & 10 & 60 & 20 \\
\hline
\end{tabular}

\begin{tabular}{|c|c|c|c|c|}
\hline 6 & 40 & 10 & 40 & 20 \\
\hline 7 & 40 & 10 & 40 & 10 \\
\hline 8 & 40 & 10 & 40 & 20 \\
\hline 9 & 40 & 0 & 20 & 10 \\
\hline 10 & 40 & 0 & 20 & 10 \\
\hline
\end{tabular}

It can be seen that planting material treatment significantly reduces mold damage. Garlic overwintering is presented in Table 3.

Table 3

Wintering of garlic, \%

\begin{tabular}{|c|c|c|}
\hline Ser. № & Merefyanskiy white & Duchess \\
\hline 1 & 77.5 & 72.5 \\
\hline 2 & 67.5 & 75.0 \\
\hline 3 & 65.0 & 90.0 \\
\hline 4 & 87.5 & 92.5 \\
\hline 5 & 77.5 & 92.5 \\
\hline 6 & 92.5 & 97.5 \\
\hline 7 & 80.0 & 95.0 \\
\hline 8 & 90.0 & 100.0 \\
\hline 9 & 77.5 & 95.0 \\
\hline 10 & 75.0 & 92.5 \\
\hline
\end{tabular}

It can be seen that the percentage of successfully overwintered garlic significantly increases from $77.5 \ldots 72.5$ to $90 \ldots 100 \%$ after ozone treatment. The average plant height in the test plots is presented in Table 4.

Plant height, $\mathrm{cm}$

\begin{tabular}{|c|c|c|}
\hline Ser. № & Merefyanskiy white & Duchess \\
\hline 1 & 78.4 & 68.2 \\
\hline 2 & 84.6 & 72.0 \\
\hline 3 & 85.6 & 71.3 \\
\hline 4 & 88.0 & 72.2 \\
\hline 5 & 84.8 & 74.3 \\
\hline 6 & 87.4 & 71.6 \\
\hline 7 & 82.4 & 70.6 \\
\hline 8 & 84.6 & 68.5 \\
\hline 9 & 83.2 & 68.6 \\
\hline 10 & 82.2 & 74.6 \\
\hline
\end{tabular}

The table shows that the average plant height has increased after the treatment. Decreasing the fungus infestation provided better wintering conditions for plants and ensured increasing their yield. Garlic yield on the test plots is presented in Table 5 .

Table 5

Garlic yield, t/ha

\begin{tabular}{|c|c|c|}
\hline Ser. № & Merefyanskiy white & Duchess \\
\hline 1 & 5.0 & 3.8 \\
\hline 2 & 5.6 & 5.7 \\
\hline 3 & 6.4 & 6.4 \\
\hline 4 & 7.5 & 5.8 \\
\hline 5 & 6.5 & 7.0 \\
\hline 6 & 7.5 & 7.2 \\
\hline
\end{tabular}




\begin{tabular}{|c|c|c|}
\hline 7 & 6.1 & 6.9 \\
\hline 8 & 7.7 & 6.3 \\
\hline 9 & 6.4 & 6.3 \\
\hline 10 & 6.4 & 8.3 \\
\hline
\end{tabular}

The table shows that the yield averaged $6.67 \mathrm{t} / \mathrm{h}$ for variety Meref'yanskiy white and $6.65 \mathrm{t} / \mathrm{h}$ for Duchess and increased by $33 \ldots 75 \%$ relative to the test plot after treatment. Biochemical compositions of garlic varieties are presented in Tables 6,7 .

Table 6

Biochemical composition of Merefyanskiy white

\begin{tabular}{|c|c|c|c|c|}
\hline $\begin{array}{c}\text { Ser. } \\
\text { № }\end{array}$ & $\begin{array}{c}\text { Dry sub- } \\
\text { stance, \% }\end{array}$ & $\begin{array}{c}\text { Total } \\
\text { sugar, \% }\end{array}$ & $\begin{array}{c}\text { Nitrates, } \\
\mathrm{mg} / \mathrm{kg}\end{array}$ & $\begin{array}{c}\text { Ascorbic acid, } \\
\mathrm{mg} / 100 \mathrm{~g}\end{array}$ \\
\hline 1 & 35.73 & 32.88 & 12.8 & 9.50 \\
\hline 4 & 35.07 & 31.48 & 10.9 & 8.70 \\
\hline 7 & 37.31 & 32.40 & 11.1 & 8.22 \\
\hline 10 & 37.01 & 28.60 & 10.8 & 8.73 \\
\hline
\end{tabular}

Table 7

Biochemical composition of Duchess

\begin{tabular}{|c|c|c|c|c|}
\hline $\begin{array}{c}\text { Ser. } \\
\text { № }\end{array}$ & $\begin{array}{c}\text { Dry sub- } \\
\text { stance, \% }\end{array}$ & $\begin{array}{c}\text { Total } \\
\text { sugar, \% }\end{array}$ & $\begin{array}{c}\text { Nitrates, } \\
\mathrm{mg} / \mathrm{kg}\end{array}$ & $\begin{array}{c}\text { Ascorbic acid, } \\
\mathrm{mg} / 100 \mathrm{~g}\end{array}$ \\
\hline 1 & 37.08 & 33.40 & 8.90 & 8.22 \\
\hline 4 & 38.34 & 30.60 & 7.71 & 10.00 \\
\hline 7 & 36.14 & 31.04 & 7.66 & 7.70 \\
\hline 10 & 35.56 & 31.48 & 8.06 & 10.80 \\
\hline
\end{tabular}

The tables show that accumulation of nitrates and sugar in garlic decreased after pre-sowing treatment with ozone.

Ozone treatment reduces the proportion of garlic affected by black mold from 55 to $40 \%$, and this effect is achieved when treated for $100 \mathrm{~min}$ at ozone concentration of 100 PPM.

As a result of studying the effect of the ozone-air mixture on the viability of microorganisms, decrease of mold damage was observed in all studied garlic varieties. On average it was $20 \ldots 70 \%$, respectively.

\section{CONCLUSIONS}

The use of ozone for pre-planting treatment of planting material of winter garlic in a concentration of 10 to 100 PPM and exposure up to $100 \mathrm{~min}$ tends to reducing fungal diseases by 1.1-2.0 times depending on the pathogen type and ozonation mode. Pre-planting treatment of winter garlic with ozone at a concentration of $50 \mathrm{PPM}$ and an exposure of $60 \mathrm{~min}$ (Option 6) is the most appropriate. Decrease in the incidence of fungal diseases, increase in biometric indicators, improved adaptive properties and increased yields were observed. No significant effect on organoleptic and biochemical parameters was observed.

\section{REFERENCES}

1. J.Y. Oh, K.D. Kim. Control Strategies for Fungal Pathogens on Stored Onion (Allium cepa) and Garlic (Allium sativum): A Review // Life Science and Natural Resources Research. 2016, № 24, p. 31-40.

2. A.A. Kolesnik. Factors of long-term storage of fruits and vegetables. M.: "Gostorgizdat", 1959, p. 356.

3. F.A. Miller, L.M. Silva, T.R.S. Branda. Review on Ozone-Based Treatments for Fruit and Vegetables Preservation // Food Eng Rev. 2013, 5:77-106; DOI:10.1007/s12393-013-9064-5.

4. G.V. Taran, V.A. Breslavets, A.A. Zamuriev, et al. Plasma-chemical methods for control of biotic contaminants // Problems of Atomic Science and Technology. Series "Plasma Electronics and New Methods of Acceleration”. 2019, № 4, p. 198-202.

5. L.J. Skog, and C.L. Chu. Effect of ozone on qualities of fruits and vegetables in cold storage // Canadian Journal of Plant Science. 2001, v. 81(4), p. 773-778; doi:10.4141/P00-110.

6. V.I. Golota, G.V. Taran, A.A. Zamuriev, P.O. Opalev, S.G. Pugach, S.M. Mankovskiy, V.P. Petrenkova, I.N. Nyska. The use of ozone technologies in grain storage // Problems of Atomic Science and Technology. 2018, № 4 (116), p. 185-188.

Article received 16.06.2021

\section{ОПРЕДЕЛЕНИЕ ОПТИМАЛЬНОГО РЕЖИМА ОЗОНИРОВАНИЯ ПОСАДОЧНОГО МАТЕРИАЛА «ЧЕСНОК}

ОЗИМЫЙ»

\section{С.Г. Пугач, Л.М. Завада, А.А. Замуриев, Д.В. Кудин, П.О. Опалев, А.В. Мельник, С.А. Щербина, О.Л. Семенченко}

Исследование проведено в Институте овощеводства и бахчеводства НААН Украины и отделе низкотемпературной неравновесной плазмохимии ННЦ «Харьковский физико-технический институт» НАН Украины на сортах чеснока озимого «Дюшес» и «Мерефянский белый». Предпосадочная обработка осуществлась за 3-5 суток до посадки с помощью озонатора серии OzW StreamOzone TM с четырехразовым повторением. Лабораторные исследования по развитию грибных болезней родов Fusarium и Penicillium на обработанном материале выполняли с использованием влажных камер в четырехразовом повторении. Исследовано влияние концентрации озона 10, 50 и 100 ppm $\mathrm{O}_{3}$ и времени экспозиции - 10, 100 и 180 мин на пораженность чеснока черной и зеленой плесенью.

\section{ВИЗНАЧЕННЯ ОПТИМАЛЬНОГО РЕЖИМУ ОЗОНУВАННЯ САДИВНОГО МАТЕРІАЛУ «ЧАСНИК ОЗИМИЙ»}

\section{С.Г. Пугач, Л.М. Завада, О.О. Замурієв, Д.В. Кудін, Р.О. Опалєв, А.В. Мельник, С.А. Щербіна, О.L. Семенченко}

Дослідження проведено у Інституті овочівництва і баштанництва НААН України та відділі Низькотемпературної нерівноважної плазмохімії ННЦ «Харківський фізико-технічний інститут» НАН України на сортах часнику озимого «Дюшес» та «Мереф'янський білий». Передсадивну обробку здійснено за 3-5 діб до садіння за допомогою озонатора серії OzW StreamOzone TM у чотириразовому повторенні. Лабораторні дослідження щодо розвитку грибних хвороб родів Fusarium та Penicillium на обробленому матеріалі виконували з використанням вологих камер у чотириразовому повторенні. Досліджено вплив концентрацій озону 10, 50 та 100 ppm Оз та часу експозиції - 10, 100 та 180 хв на ураженість часнику чорною і зеленою пліснявою. 